\title{
Photochemical Study and Biological Activity of Phenolic Compounds of Three Varieties of Durum Wheat (Triticum Durum.Desf) Subjected to Water Stress
}

\author{
Ghania Chaib, and Marwa Ghorab et Sabira Djaaleb
}

\begin{abstract}
Our work has focused on the quantitative and qualitative study of polyphenols both with and without water deficit treatments (WD) and (NWD) respectively, applied on three varieties of durum wheat (Triticum durum Desf.): Haurani, Hedba and GuemgoumRkham. The results of the quantitative analysis of ethanol extracts showed that the polyphenols content is considerable, in the three varieties under the two treatments. The qualitative study of polyphenols begins with allocations between four solvents with different polarities. This leads to the obtaining of different phases. Their compositions were identified by UV-Visible Spectrophotometer and Thin Layer Chromatographic Analysis (TLC). The results distinguished four groups of phenolic compounds at WD treatment (1, 5,6 and 8). While it shows, only three groups at NWD treatment $(3,5$ and 6). Which indicates that the majority of polyphenols detected are single phenols, phenolic acids and flavonoids (mainly flavone and flavonol-type)? The antimicrobial activity test revealed that the methanol extracts have a strong antibacterial activity especially Bacillus (WD treatment). Whereas in fungi there is no resistance against Fusarium sp.
\end{abstract}

Key words: Wheat (Triticum Durum Desf.), Polyphenols, Water Deficit, UV-Visible Spectrophotometer, Antimicrobial, TLC.

\section{INTRODUCTION}

The environment in Algeria is marked by drought, cold and hot weather which are often present. These production constraints are also combined with each other, worsening the performance of durum wheat [1].

The plants which are capable of producing a wide variety of products do not participate in their basic metabolism, but rather represent products with secondary metabolism [2]- [3]. Among these compounds, polyphenols are one of the largest groups due to their low toxicity and numerous biological benefits including therapeutic [3] pharmaceutical, cosmetic and nutritional.

In the recent years, we have witnessed a significant upsurge

Manuscript received October 19, 2015. This work was supported by Laboratory of Development and Valorization of Resources Phytogenetics, Department of Biology and Ecology, Faculty of live Sciences and Nature University of Constantine Mentouri, Algeria.

Ghania Chaib ., Laboratoire de Développement et Valorisation de Ressources Phytogénétiques, Département de Biologie et Ecologie Végétale Faculté des Sciences de la Nature et de la Vie. Université Frères Mentouri Constantine. Algérie.z

Ghorab Marwa et Djaaleb Sabira, Département de Biologie et Ecologie Végétale Faculté des Sciences de la Nature et de la Vie. Université Frères Mentouri Constantine. Algérie. of herbalists in the products rich in polyphenols, mainly flavonoids. They showed that they had very important and very large biological properties [4].

Plants rapidly synthesize defense substances against attacks by micro-organisms [5] they have several lines of defense against pathogens. Subsequent translations include rapid production of oxygen derivatives and the synthesis of phenolic compounds [6]. Phenolic compounds play a significant part in the plants metabolism, they protect also the plants against the aggressions of different pathogenic organisms [7], and they are actively involved in the interactions of the plants with its environment; they are acting as recognition signals between plants or as a mean of resistance [8]. They contribute very effectively in the plant tolerance to various stresses. So these compounds play a vital role in the balance and the adaptation of the plant to its natural environment [3].

In humans, these molecules traces are important in acting directly on the nutritional quality of fruits and vegetables and their impact on the consumer's health (antioxidant, protective effect against the development of certain cancers ...) [9]-[10].

This study is used to compare the total polyphenol content of the extracts of the three varieties of durum wheat processed with and without water deficit (WD and NWD), to reveal the richness of these cereals in phenolic compounds and test their antimicrobial activities in vitro namely antibacterial and antifungal.

\section{MATERIALS AND METHODS}

\section{Plant Material}

The study focused on three varieties of durum wheat (Triticum durum) Haurani (HAU) Hedba3 (HED) and Guemgoum Rkham (GGR). The planting of these three varieties was conducted January 15, 2014 in round pots containing about $3 \mathrm{~kg}$ of clay loam soil. Five seeds of each variety of durum wheat were seeded with an average of nine repeats for the purpose of studying two planes, phenolic compounds in normal state (NWD without water deficit) and phenolic compounds with water deficit (WD).

Seedlings were irrigated once a week during the early life stages of the plant with 1/4 field capacity. At the four-leaf stage, the test was partitioned to two treatments: the first pots were irrigated twice a week. While the remaining pots were subjected to watering stops by applying water stress. The three varieties were harvested during the bolting stage under the two treatments WD and NWD.

\section{Phytochemical Study}




\subsection{Quantitative Study (polyphenol content)}

The determination of total phenols helps the identification of phenolic compounds content in $1 \mathrm{~g}$ of the vegetal material. This latter is ground in a water / ethanol mixture (50/50) and macerated for 24 hours [11].

The content of phenolic compounds of our extracts is estimated by the Folin Ciocalteu method [12] and determined by spectrophotometery following the protocol of Miliauskas et al. [13]. The quantification of the phenolic compounds is calculated based on a linear calibration curve prepared by a standard extract of Gallic acid [14]. The results are expressed in milligrams Gallic acid equivalent per gram of the plant dry weight.

2.2. Qualitative Study (Extraction, identification and separation of phenolic compounds).

\section{A. Extraction}

Plant material with a $20 \mathrm{~g}$ weight is cut into small pieces. It is macerated in a mixture of ethanol-distilled water (50/50). The ratio of plant material / aqueous-alcoholic solution is $1 / 10 \mathrm{ml} / \mathrm{g}$ [15]. The whole rests for 72 hours with renewal of solvent 3 times every 24 hours with filtration. The extracts obtained are faced by various organic solvents from the less to the most polar. The clashes lead to the obtaining of four phases: diethyl ether phase (DE) ethyl acetate phase (AE), butanone phase (MEK) and aqueous or residual phase (H2O). All phases are evaporated to dryness at $50^{\circ} \mathrm{C}$, except the solvent in the diethyl ether layer is evaporated in the open air [16]. The recovery of the residues is carried out with $5 \mathrm{ml}$ of methanol.

\section{B. Identification}

\section{Spectral Analysis}

The reparted phases obtained and the residual phases are passed in a spectral analysis to identify phenolic compounds dissolved in each solvent.

The analysis of phenolic compounds by a scrolling UV-Visible spectrophotometer is between 220 and $400 \mathrm{~nm}$ [14]. This device is calibrated by methanol. Then, a drop of the phase to be analyzed is added to the methanol. The spectrum is obtained with its peaks.

\section{Thin Layer Chromatographic Analysis}

The plates used are made of glass $(20 / 20 \mathrm{~cm}$ and 20/10). The selected adsorbent is silica gel TLC. The system chosen for the three-phase Diethyl ether, ethyl acetate and butanone is 50/20/25/2: distilled H2O / n Butanol / Ethanol / acetol. Whereas, the aqueous phase is carried out by the solvent system 50/20/25: distilled H2O / n Butanol / EtOH. The eluent was poured to a height of $1 \mathrm{~cm}$ in an elution vessel sealed to vapor saturation. The deposition of samples is evenly using a capillary glass pipette without digging the solid support [17], where a line of $3 \mathrm{~mm}$ is marked with a pencil about $2 \mathrm{~cm}$ from the bottom side of the plate. The diameter of the spot produced is dried quickly between each application; the plate placed vertically in the tank should remain closed and not to be moved when the solvent front reaches approximately $1 \mathrm{~cm}$ from the upper end, the plate is removed from the vessel. The level reached by the solvent is characterized by a thin line. The plate is dried in the open air [18] reinforced with a dryer. The distances traveled by different spots are measured by the front ratio (FR).

$\mathrm{FR}=$ Distance traveled by the substance / solvent front traveled distance

To the naked eye it is very difficult to identify all the spots. For this reason, the plates are passed to the dark room to visualize them using a UV lamp and with a spray of sulfuric acid, acetic acid and distilled water. The revelation made the spots more remarkable

\section{Biological Activity (Antibacterial and Antifungal):}

The microorganisms tested in this study are the bacteria's Escherichia coli and Bacillus, and the fungus Fusarium sp which were isolated from the pathological laboratory products of the university's hospital in Constantine, Algeria. Evaluation of the antimicrobial activity was performed by disk diffusion method [19] - [20].

In this experiment, $100 \mathrm{ml}$ of the ethanolic extract was used in each variety. After evaporation to dryness, the residue is recovered with $5 \mathrm{ml}$ of ethanol. A Whatman paper sheet is cut into discs of $6 \mathrm{~mm}$ diameter sterilized in an autoclave at $120^{\circ} \mathrm{C}$ for $20 \mathrm{~min}$. Then they are soaked in three sterilized tubes each containing an ethanol extracts of each variety. The nutrient media employed are respectively Potato Detrox Agar (PDA) for fungi and nutrient agar for bacteria GN.

The same procedure is used for sterilization of the GN. Agar (GN and PDAs) are melted and cast in Petri dishes in half. Once the agar is solidified completely, A suspension of either bacterial or fungal of $10 \mu \mathrm{l}$ is spread over the agar by a sterile rake (The discs impregnated in the ethanolic extracts are carefully deposited half dried by means of a clamp on the suspension). The well closed dishes are incubated respectively in ovens at $30^{\circ} \mathrm{C}$ for 72 hours for fungus and at $37^{\circ} \mathrm{C}$ for 24 hours for the bacteria. The diameters of the inhibition zones are measured using a caliper. An extract is considered active when measuring a zone of inhibition around the disc is in diameter greater than $6 \mathrm{~mm}$ [21].

\section{Statistical analysis}

The results obtained represent the average of three replicates for both phytochemical and biological studies. The statistical test performed is the variance analysis of two factors, followed by a comparison test of Newman-Keuils mean (SNK) at a 95\% confidence threshold performed by the software stat Excel 2014 release.

\section{RESULTANTS AND DISCUSSION}

\section{Phytochemical study}

\subsection{Determination of polyphenols (Quantitative aspect)}

The levels of total phenols varies among the three varieties of durum wheat in the elongation stage at WD from $41.86 \pm 15.91$ phase $\mathrm{mg} / \mathrm{g}$ Gallic acid equivalent (eq AC) to $23,24 \pm 2.42 \mathrm{mg}$ / g eq AC. The maximum value is recorded in the Hau variety, while the minimum value is recorded in the Hed variety. The variety GGR marks a $37.20 \mathrm{mg} / \mathrm{g}$ AC eq intermediary holding $\pm 8.87 \mathrm{mg} / \mathrm{g} \mathrm{AC}$ eq. On the other hand; the NWD phase 
polyphenols contents vary among the three varieties from 46.28 $\pm 12.93 \mathrm{mg} / \mathrm{g} \mathrm{AC}$ eq at GGR as maximum value to $13.07 \pm$ $4.10 \mathrm{mg} / \mathrm{g} \mathrm{AC}$ eq at Hed as minimum value. The variety Hau marks an intermediate grade of $29.24 \pm 4.46 \mathrm{mg} / \mathrm{g}$ AC eq.

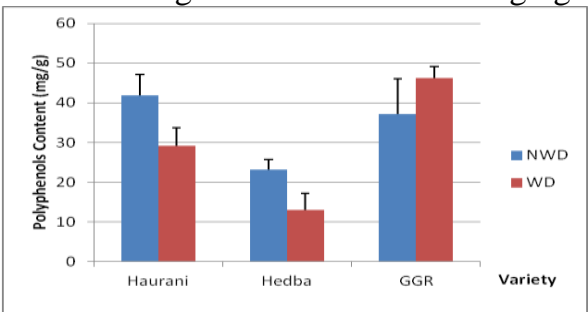

Fig .1 Polyphenols Content In The Three Wheat Varieties In Two Treatments NWD And WD.

In relation to the contents recorded in the two varieties treatments studied, total polyphenols reduced in the NWD by 1/4 phase and by half in both HAU and HED varieties respectively from the WD phase. But this content slightly increased in the GGR variety by range of 1/6.

The two factors variance analysis revealed a significant difference between the three studied varieties. But it does not reflect any statistical significant difference between the two WD and NWD treatment.

According to the SNK test, tow groups include the three studied varieties with a simple difference in the average between them.

\section{HED $\leq$ HAU $\approx$ GGR $\Leftrightarrow 18,153 \leq 35,512 \approx 41,740$}

Also, the SNK test combines the two treatments in one group:

$$
\text { WD } \approx \text { NWD } \Leftrightarrow 29,529 \approx 34,075 \text {. }
$$

\subsection{Identification and extraction of polyphenols (qualitative aspects)}

\section{A. Extraction}

The difference in color phases of diethyl ether, ethyl acetate and MEK may be related to different concentrations of polyphenols and their types included in each phase (Table I).

TABLE I

Phases ObTained AFTER CONFRONTATIONS In Two TREATMENTS (NWD

\begin{tabular}{|c|c|c|c|c|c|c|c|}
\hline \multicolumn{8}{|c|}{ AND WD) } \\
\hline & 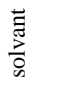 & 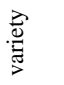 & $\frac{0}{0}$ & 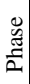 & $\begin{array}{l}\overrightarrow{0} \\
\stackrel{0}{0} \\
0 \\
0\end{array}$ & $\underset{\frac{0}{0}}{\frac{0}{7}}$ & $\frac{\dot{0}}{0}$ \\
\hline \multirow{12}{*}{ 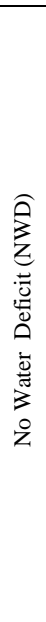 } & \multirow{3}{*}{ EP } & HAU & greenish yellow & & \multirow{3}{*}{ EP } & HAU & greenish yellow \\
\hline & & HED & greenish yellow & & & HED & greenish yellow \\
\hline & & GGR & greenish yellow & & & GGR & greenish yellow \\
\hline & \multirow{3}{*}{$\mathrm{DE}$} & HAU & Light green & & \multirow{3}{*}{$\mathrm{DE}$} & HAU & Light green \\
\hline & & HED & Light green++ & & & HED & Light green++ \\
\hline & & GGR & Light green & 2ิ & & GGR & Dark green \\
\hline & \multirow[t]{3}{*}{ EA } & HAU & $\begin{array}{l}\text { Light greenish } \\
\text { yellow }\end{array}$ & $\begin{array}{l}0 \\
0 \\
0 \\
0 \\
0 \\
0\end{array}$ & \multirow[t]{3}{*}{ EA } & HAU & $\begin{array}{c}\text { Light greenish } \\
\text { yellow }\end{array}$ \\
\hline & & HED & $\begin{array}{l}\text { Light greenish } \\
\text { yellow }\end{array}$ & $\sum^{\pi}$ & & HED & $\begin{array}{c}\text { Light greenish } \\
\text { yellow }\end{array}$ \\
\hline & & GGR & greenish yellow & & & GGR & greenish yellow \\
\hline & \multirow{3}{*}{ MEK } & HAU & Light yellow & & \multirow{3}{*}{$\begin{array}{c}\mathrm{ME} \\
\mathrm{C}\end{array}$} & HAU & Light yellow \\
\hline & & HED & brown & & & HED & greenish yellow \\
\hline & & GGR & yellow & & & GGR & greenish yellow \\
\hline
\end{tabular}

The phase's colors are clearly different which helps to conclude that each phase contains some phenolic compounds. The residual aqueous phases from the clashes are shown in Table II.

TABLE II

RESIDUAL PHASES (NWD AND WD)

\begin{tabular}{|c|c|c|c|}
\hline \multirow{4}{*}{$\mathrm{H} 2 \mathrm{O}$} & Variety & NWD & WD \\
\hline & HAU & Light brown & Dark brown \\
\hline & HED & Light brown & Dark brown \\
\hline & GGR & Dark brown & Light brown \\
\hline
\end{tabular}

\section{B. Identification}

\section{Spectral Analysis}

In the UV-visible range, the methanolic solutions of diethyl ether phase in both WD and NWD treatments for the majority give four peaks located between $222 \mathrm{~nm}$ and $276 \mathrm{~nm}$. This allows us to deduce that this phase does not contain flavonoids and assume that these peaks may represent simple phenols and Phenolic acids.

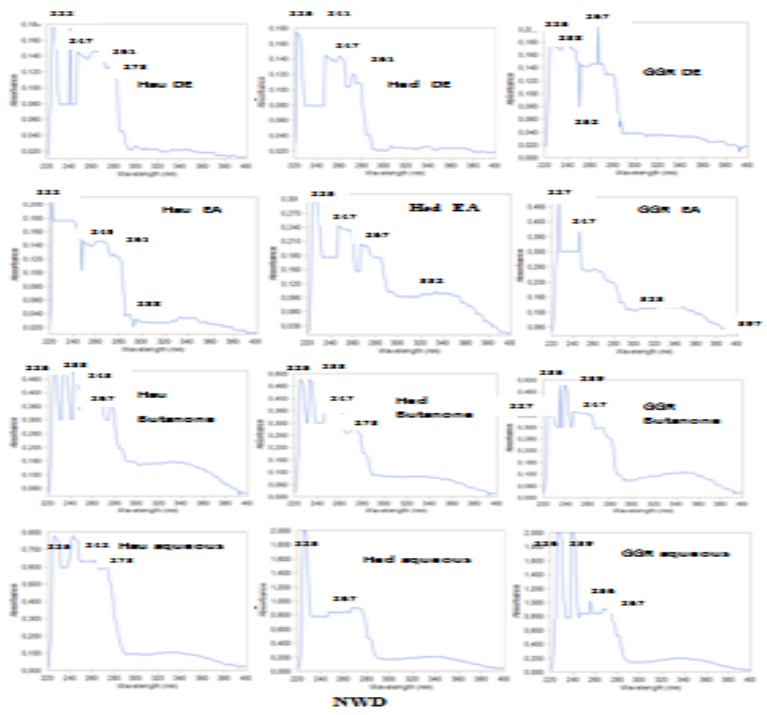

Fig. 2. Specters Of Phases In NWD Treatment.

The methanolic solutions of the acetate phase were found for most flavonoic solutions giving four peaks situated in the 222-397 nm intervals. The revealed spots of ether diethylic phase give more distinct peaks (therefore more pure) which are strongly nearing those of the butanone phase. The first two peaks found in between 222 and $225 \mathrm{~nm}$ characterizes a simple phenol or phenolic acid. The other two peaks are between 225 and $397 \mathrm{~nm}$. This interval is characteristic of flavonoids. Bousmid [14] found that after the spectral analysis of pure compounds of the phases of ethyl acetate and butanone, pure compounds of these phases are flavonoids. Our results agree with those of Wagner and Bladt [22]-[15] and Chaib et al. [23], who report that flavonoids are found by two peaks. The first is between 230 and $280 \mathrm{~nm}$, the second appears at about 300 and $385 \mathrm{~nm}$. 


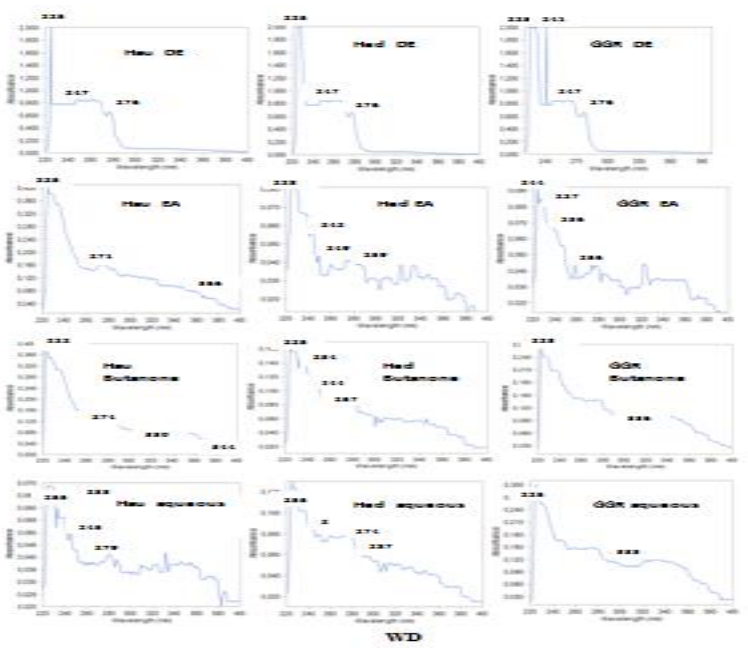

Fig. 3. Specters Of Phases In The WD Treatment.

\section{Chromatographic Analysis}

The results of the chromatographic analysis are introduced in Figures (4, 5, 6 and 7).
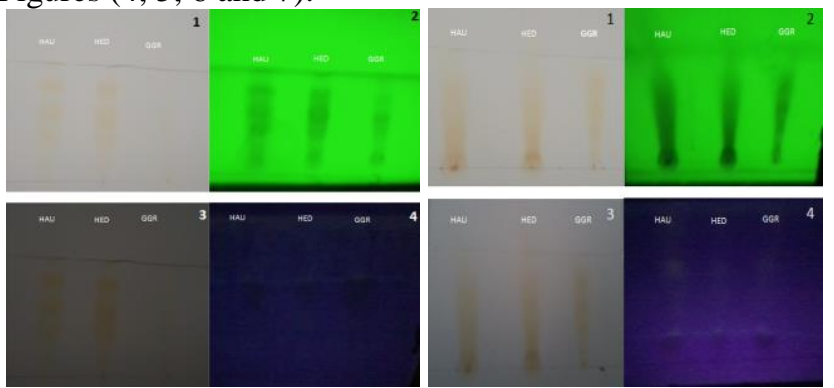

NWD: No Water Deficit; WD: Water Deficit; DE: Dicityl ether; EA: Ethyl Acetate; MEK: Methyl Ethyl Ketone. 1: Visible, 2: Under UV, 3: Visible after pulverization with sulfuric acid 50\%, 4: UV after pulverization.

Fig. 4. The three varieties aqueous phase TLC in two treatments NWD and $\mathrm{WD}$, in the system $\mathrm{H} 2 \mathrm{O}$ distilled/n Butanol/EtOH $(50,20,25)$.
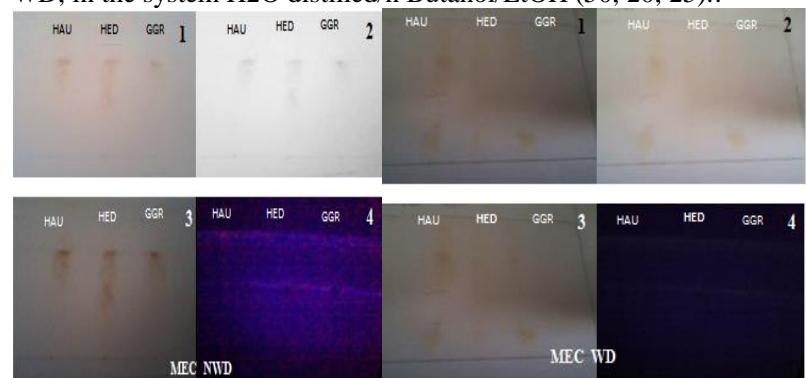

NWD: No Water Deficit; WD: Water Deficit; DE: Diethyl ether; EA: Ethyl Acetate; MEK: Methyl Ethyl Ketone. 1: Visible, 2: Under UV, 3: Visible after pulverization with sulfuric acid 50\%, 4: UV after pulverization

Fig. 5. Durum wheat three varieties Methyl Ethyl Ketone Phase TLC, in two treatments (WD and NWD) in the system Tol / MEK / ETOH / Ether Petrol

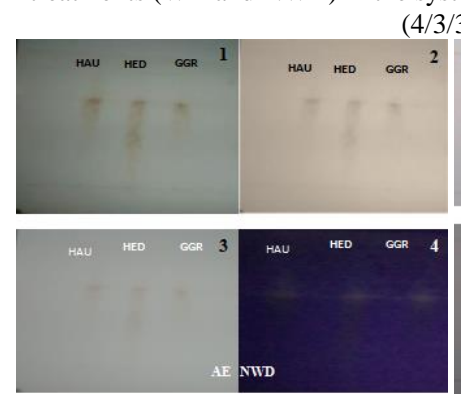
$(4 / 3 / 3 / 5)$

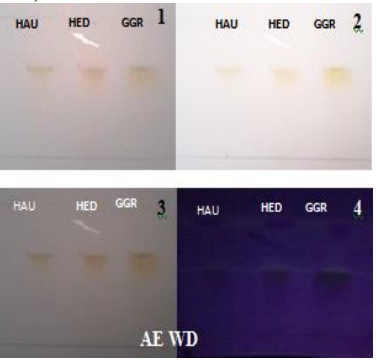

NWD: No Water Deficit; WD: Water Deficit; DE: Diethyl ether; EA: Ethyl Acetate; MEK: Methyl Ethyl Ketone. 1: Visible, 2: Under UV, 3: Visible after pulverization with sulfuric acid 50\%, 4: UV after pulverization.

Fig. 6. Durum wheat three varieties Ethyl Acetate phase TLC in the two treatments WD and NWD in the system Tol / MEK / ETOH / Ether Petrol $(4 / 3 / 3 / 5)$.

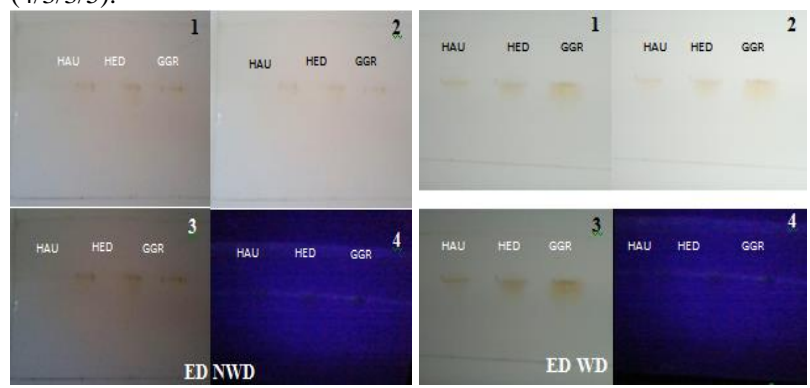

NWD: No Water Deficit; WD: Water Deficit; DE: Diethyl ether; EA: Ethyl Acetate; MEK: Methyl Ethyl Ketone. 1: Visible, 2: Under UV, 3: Visible after pulverization with sulfuric acid 50\%, 4: UV after pulverization.

Fig. 7. Durum wheat three varieties diethyl ether phase TLC in two treatments (WD and NWD) in the system Tol / MEK / ETOH / Ether Petrol (4/3/3/5).

TABLE III

THE Frontal RePORTS AND COLORS OF THE SPECKS In THE TLC (NWD)

\begin{tabular}{|c|c|c|c|c|}
\hline Variety & Phase & $\mathrm{N}^{\circ}$ Spots & $\mathrm{R}_{\mathrm{f}}$ & Color \\
\hline \multirow{10}{*}{ HAU } & ED & 1 & 0,61 & yellow \\
\hline & & & 0,64 & bright yellow \\
\hline & $\mathrm{AC}$ & 2 & 0.96 & mauve \\
\hline & & & 0,16 & Yellow green \\
\hline & MEK & 3 & 0,67 & bright yellow \\
\hline & & & 0,94 & Yellow green \\
\hline & & & 0,16 & White \\
\hline & $\mathrm{H} 2 \mathrm{O}$ & 4 & 0,37 & Yellow \\
\hline & & & 0,67 & White \\
\hline & & & 0,88 & oronge \\
\hline \multirow{9}{*}{ HED } & ED & 1 & 0,63 & yellow \\
\hline & & & 0,64 & Yellow \\
\hline & $\mathrm{AC}$ & 2 & 0,96 & mauve \\
\hline & & & 0,28 & Yellow green \\
\hline & MEC & 3 & 0,51 & Yellow \\
\hline & & & 0,69 & brown \\
\hline & & & 0,28 & Yellow \\
\hline & $\mathrm{H} 2 \mathrm{O}$ & 3 & 0,51 & Yellow green \\
\hline & & & 0,69 & White \\
\hline \multirow{10}{*}{ GGR } & ED & 1 & 0,63 & Yellow green \\
\hline & & & 0,65 & bright yellow \\
\hline & $\mathrm{AC}$ & 2 & 0,96 & mauve \\
\hline & & & 0,14 & Yellow green \\
\hline & MEK & 3 & 0,68 & Yellow \\
\hline & & & 0,91 & green \\
\hline & & & 0,9 & White \\
\hline & & & 0,65 & Yellow green \\
\hline & $\mathrm{H} 2 \mathrm{O}$ & 4 & 0,77 & Yellow green \\
\hline & & & 0,86 & oronge \\
\hline
\end{tabular}


According to Tables III and IV, the spots number in the two phases of NWD and WD treatments are the same.

The diethyl ether phases showed a single spot color, indicating that they are rich in phenolic acids and simple phenol in both WD and NWD treatments. The Ethyl Acetate phases showed two spots for the majority. On the other part, the Butanone Phase records three spots in the WD process and a single spot in the NWD process. The aqueous phases are rich in flavonoids and showed for all four varieties three spots at both treatments.

TABLE IV

THE FRONTAL REPORTS AND COLORS OF THE SPECKS IN THE TLC (WD)

\begin{tabular}{|c|c|c|c|c|}
\hline variety & Phase & $\mathrm{N}^{\circ}$ Spots & $\mathrm{R}_{\mathrm{f}}$ & Color \\
\hline \multirow{7}{*}{ HAU } & ED & 1 & 0,73 & orange \\
\hline & $\mathrm{AC}$ & 1 & 0,61 & yellow \\
\hline & MEC & 1 & 0,66 & bright yellow \\
\hline & & & 0,08 & White \\
\hline & & & 0,27 & Yellow \\
\hline & $\mathrm{H} 2 \mathrm{O}$ & 4 & 0,65 & Yellow green \\
\hline & & & 0,76 & orange \\
\hline \multirow{9}{*}{ HED } & & & 0,73 & Orange \\
\hline & ED & 2 & 0,92 & Dark yellow \\
\hline & & & 0,37 & Orange \\
\hline & AC & 2 & 0,67 & Dark yellow \\
\hline & & & 0,66 & Orange \\
\hline & MEK & 2 & 0,88 & bright yellow \\
\hline & & & 0,06 & Yellow \\
\hline & & & 0,56 & White \\
\hline & $\mathrm{H} 2 \mathrm{O}$ & 3 & 0,62 & orange \\
\hline \multirow{7}{*}{ GGR } & ED & 1 & 0,77 & Yellow green \\
\hline & & & 0,37 & oronge \\
\hline & $\mathrm{AC}$ & 2 & 0,69 & Dark yellow \\
\hline & MEK & 1 & 0,66 & bright yellow \\
\hline & $\mathrm{H} 2 \mathrm{O}$ & 3 & 0,09 & Yellow \\
\hline & & & 0,59 & White \\
\hline & & & 0,65 & oronge \\
\hline
\end{tabular}

We note that the frontal Reports range from 0.61 and 0.96 for WD . They are very close to those of the stadium NWD varying between 0.06 and 0.88 (Table V).

Table V: Frontal reports intervals for the four phases.

\begin{tabular}{|c|c|c|}
\hline $\begin{array}{c}\text { Treatments } \\
\text { Phases }\end{array}$ & NWD & WD \\
\hline diethyl ether & $0.61-0.63$ & $0.73-0.77$ \\
\hline Ethyl acetate & $0.64-0,96$ & $0.09-0.37$ \\
\hline Butanone & $0,14-0.94$ & $0.66-0.88$ \\
\hline $\mathrm{H}_{2} \mathrm{O}$ & $0.9-0.88$ & $0.06-0.77$ \\
\hline
\end{tabular}

According to the FR the identification of flavonoids in each phase is possible [24]. Bandykova and Shinkarenko [25] claimed that the flavonols and flavanones are characterized by an FR between 0.3 and 0.5 . Therefore and according to the two tables II and IV, it can be assumed that the phases contain the following types of flavonoids (the numbers in Table VI are used in Table VII to replace the types of flavonoids mentioned in the same line)

TABLE VI

RELATION BETWEEN FLUORESCENCE UNDER UV AND FLAVONOIDS STRUCTURE [26]

\begin{tabular}{|l|l|}
\hline \multicolumn{1}{|c|}{ Spot Colored } & Flavonoids Type \\
\hline 1-Black-Brown & $\begin{array}{c}\text { Flavonols 5, 6, 7 Tris-Oh Free } \\
\text { Flavonols 5, 7, 8 Tris-Oh }\end{array}$ \\
\hline 2-Brown Black & 3-Oh Absent Or 3-Oh Substituted \\
\hline $\begin{array}{l}\text { Flavones 5-Oh Et 4'-Oh Flavones 3-Or } \\
\text { Et 5-Oh, 4'-Oh } \\
\text { Flavones Ou Flavonols 5-Oh Avec } \\
\text { 4'-Oh Absent Or Substituted In 3. } \\
\text { Flavones 6- Or 8-Oh } \\
\text { Chalcones Isoflavones, } \\
\text { Dihydroflavanols, Flavanones. }\end{array}$ \\
\hline $\begin{array}{l}\text { Flavones Without 5-Oh Free } \\
\text { Flavones Without 5-Oh Free With } \\
\text { (Fluorescent) }\end{array}$ & $\begin{array}{l}\text { Flavonols 3-Oh Free With Or Without } \\
\text { 5-Dull Yellow, } \\
\text { Yellow, Fluorescent } \\
\text { Orange }\end{array}$ \\
\hline $\begin{array}{l}\text { 6- Bright Yellow } \\
\text { Green }\end{array}$ & 5-Oh Substituted \\
\hline 7- Fluorescent Yellow & Flavonols With 3-Oh Free \\
\hline 8-Pale Yellow & Dihydroflavanols \\
\hline
\end{tabular}

TABLE VII

The Flavonoids Contained In EACH TREatMent (WD AND NWD) PHaSE

\begin{tabular}{|c|c|c|}
\hline Phases & NWD & WD \\
\hline diethyl ether & $(6),(5)$ & $(5),(8),(6)$ \\
\hline Ethyl acetate & $(6),(3),(5)$ & $(8),(5)$ \\
\hline Butanone & $(5),(6)$ & $(6),(5),(1)$ \\
\hline $\mathrm{H}_{2} \mathrm{O}$ & $(6),(5)$ & $(5),(6)$ \\
\hline
\end{tabular}

It is observed that there are four groups of the phenolic compounds in the treatment $\operatorname{WD}(1,5,6$ and 8$)$. But, there is only three treatment groups NWD (3,5 and 6).

It can be concluded that both WD and NWD treatments mainly contain flavones and flavonols with different substitutions. On the other hand the phases of WD are characterized by the presence of Chalcones. Flavanones and isoflavones are present exclusively in the ethyl acetate layer of the WD treatment.

\section{Biological Activity}

\subsection{Antibacterial Activity}

The extract of GGR has the strongest activity against the development and growth of E.coli in WD treatment with an inhibition zone average diameter of $1.4 \pm 0.47 \mathrm{~cm}$ followed by Hau extracts with an average of $8.7 \pm 0.06$, and finally that of Hed with a weaker effect than the extracts from the other varieties $0.27 \pm 0.46 \mathrm{~cm}$. In the contrary, for NWD treatment, the methanolic extract of both varieties Hed and GGR have the most vigorous activity with an inhibition zones average diameter of $0.53 \pm 0.46 \mathrm{~cm}$ and $0.53 \pm 0.6 \mathrm{~cm}$ in succession. Hau extract marks the lower zone of inhibition by an average of $1.25 \pm 0.65 \mathrm{~cm}$ diameter (Fig.8). 
No statistical difference between the effect of the methanolic phase ethyl acetate on the E-coli and also between both NWD and WD treatments.

$\mathrm{NWD} \approx \mathrm{WD} \Leftrightarrow 0.794 \approx 0.844$

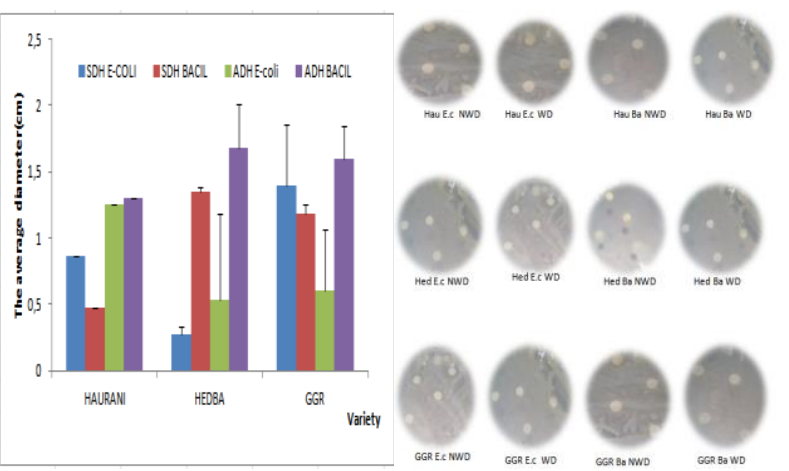

Fig 8: Disk growth inhibition zones of both E. coli and Bacillus bacteria WD and NWD treatment by extracts from three varieties of durum OF Ethyl acetate phase;

HED extract has the strongest activity against the development and growth of Bacillus in WD treatment with an inhibition zone average diameter of $0.88 \pm 0.08 \mathrm{~cm}$. While in NWD treatment, the two extracts HAU and HED have a remarkable effect with an inhibition zone average diameter of $1.22 \pm 0.25 \mathrm{~cm}$ and $1.55 \pm 0.03 \mathrm{~cm}$ in succession.

Statistical analysis indicates a significant difference between the effect of the three varieties extracts of Bacillus bacterium and also a highly significant difference between both WD and NWD treatments. The SNK test classes the studied varieties in two groups:

\section{GGR $<$ HED $\approx$ HAU $\Leftrightarrow 0.408<1.050 \approx 1.198$}

While extracts of NWD treatment have a more powerful effect than extracts of WD treatment

\section{$\mathrm{WD}<\mathrm{NWD} \Leftrightarrow 0,750 \approx 0,944$}

Statistical analysis revealed no difference between the effect of methanolic extracts of ethyl acetate Phase on the both bacteria's on both WD and NW treatments.

\section{E.coli $\approx$ Bacillus $\Leftrightarrow 0.819 \approx 0.875$}

Concerning the comparison between the two bacteria, the three-factor ANOVA showed no difference between the effects of the three varieties extracts but saves a significant difference between the effect of the two treatments and both bacteria. According to the SNK test treatments and bacteria have two different groups with the NWD extracts exert a stronger activity than the WD extracts. Bacillus also has a more rigorous effect than E. coli. Our results are consistent with those of Katarrzyna and collaborators [27] and Harikrishna et al. [28] which have demonstrated the antibacterial activity of a flavonoic glycoside (prunin 6'-Op coumarate) against two strains of Gram-positive bacteria (Bacillus subtilis and Staphylococcus albus) and two gram-negative bacteria (Escherichia coli and Proteus vulgaris).

\section{$\mathrm{WD}<\mathrm{NWD} \Leftrightarrow 0,704<1,204 ; E . C O L I<B$ ACILLUS $\Leftrightarrow 0,646<1,263$}

\subsection{Antifungal activity}

The effect of two treatments phenolic extracts of durum wheat three varieties is negative on the growth of Fusarium fungus sp.

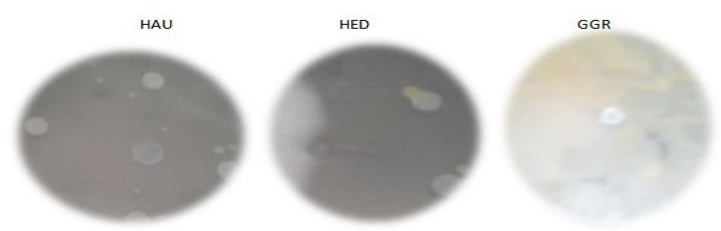

Fig10. Results Of Antifungal Activity

\section{CONCLUSION}

The quantitative study or measurement of total polyphenols indicates that each variety has significant polyphenol content. According to the statistical analysis this content means a significant difference between the three studied varieties. But it does not reflect any significant statistical difference between both WD and NWD treatments, and it varies between 29529 $\mathrm{mg} / \mathrm{g}$ eq AG and $34075 \mathrm{mg} / \mathrm{g}$ eq AG.

The phase analysis by UV -visible spectrophotometer shows that the varieties extracts are rich in simple phenols, flavonoids and phenolic acids.

The colors clearly differenced the phases which help to conclude that each phase contains some phenolic compounds.

The methanolic solutions of acetate layer revealed four peaks for all solutions flavone located at an interval 222-397 nm. Spots give more distinct peaks which are highly close to those of the butanone phase. The thin layer chromatography shows that flavones and flavonols are the most dominant flavonoids in this species.

The clashes four phase's spots number in WD treatment is similar to those in NWD treatment. The number of compounds is almost the same with an identical difference between WD and NWD. Four groups of phenolic compounds distinguished the NWD treatment. However, only three groups in WD treatment. It is concluded that both WD and NWD treatments mainly contain flavones and flavonols with different substitutions. On the other hand the WD phases are characterized by the presence of Chalcones, flavanones, and isoflavones that are present exclusively in the ethyl acetate layer of the WD. The results of the antimicrobial activity obtained show that the NWD extracts have a more inhibitory response than the ones of the WD. The bacterium extracts; Bacillus exerts a more rigorous effect against E. coli extracts. The Fusarium fungus is resistant to the extracts of the three varieties to both WD and NWD treatments. It presents a negative result.

\section{REFERENCES}

[1] Madhava Rao K.V, Raghavendra A.S. and Janardhan R, (2006) : Printed in the netherlands.physiology and molecular biology of stress tolérance in plants.Springer :1-14p.

[2] D. Malešev, V.Kuntić,. Investigation of metal-flavonoid chelates and the determination of flavonoïds via metal-flavonoïd complexing reactions. Journal of the Serbian chemical society., 2007 , 72 (10)., P: 921-939. http://dx.doi.org/10.2298/JSC0710921M

[3] Macheix J J., Fleuriet A. et Jay-Allemand C. 2005. Les composés phénoliques des végétaux : un exemple de métabolites secondaires d'importance économique. Ed Presses polytechnologiques et universitaires romandes. p4-5.

[4] G. Violet, Le monde des végétaux.2005, Science direct.net 
[5] H.Takeuchi, Z. G. Lu et T. Fujita New monoterpenes glycoside from the aerial parts of Thyme (Thymus vulgaris L). Bioscience, biotechnology and biochemistry., $2004 ; 68$ (5) : 1113http://dx.doi.org/10.1271/bbb.68.1131

[6] K.Zhou, JJ.Yin, LL.Yu, phenolic acid, tocopherol and carotenoid compositions and antioxidant functions of hard red winter wheat bran.j Agric, Food chem. 2005 May 18;53(10):3916-22 http://dx.doi.org/10.1021/jf050117c

[7] k. Ghedira Les flavonoïdes : structure, propriétés biologiques, rôle prophylactique et emplois en thérapeutique. Phytothérapie., 2005 ;3 (4) : 162-169. 87

[8] Ragaee S., Noaman K., 2006. Antioxydant activity and nutricomposition of selected cereals for food use, Science direct, Food chem., P: 32-38. http://dx.doi.org/10.1016/j.foodchem.2005.04.039

[9] N. R. Farnsworth, O. Akerele, A. S. Bingel, D. D. Soejarto et Z. Guo Places des plantes médicinales dans la thérapeutique. Bulletin de l'organisation mondiale de la santé. 1986, 64(2)., P:159-164.

[10] R. Noars, Etude de l'activité biologique des extraits du fruit de l'Elaeagnus angustifolia L1999.

[11] Liyana-Pathirana, C. M., Shahidi F., Importance of insoluble-bound phenolics Zhou K.,YinJJ., Yu LL., phenolic acid, tocopherol and carotenoid compositions and antioxidant functions of hard red winter wheat bran.j Agric, Food chem. 2005 May 18;53(10):3916-22. http://dx.doi.org/10.1021/jf050117c

[12] Adesegun S. A., Fajana A., Orabueze C. I. et Coker H. A. B. 2007. Evaluation of antioxidant propreties of Phaulopsis fascisepala $\mathrm{C} \mathrm{B} \mathrm{Cl}$ (Acanthaceae). Evidence based complementary and alternative medecine., 6 (2) : 227-231. http://dx.doi.org/10.1093/ecam/nem098

[13] G.Miliauskas, R.Venskutonis, T.A. Van Beek.,.Screening of radical scavenging activity of some medicinal and aromatic plant extract. Food chemistry; 2004,85: 231-237. http://dx.doi.org/10.1016/j.foodchem.2003.05.007

[14] A., Bousmid , "Etude des polyphénols chez le blé et l'orge:évolution au cours des stades phénologiques" Thèse de Master UMC., 2011, P: 50-75.

[15] A. Marston, K.Hostettmann, Separation and quantification of flavonoi ds. In OYvind MA, Markham KR. Chemistry, biochemistry and application. Ed. CRC Press Taylor and Francis group., 2006,P: 2-20.

[16] R.Merghem,. Eléments de biochimie végétale. 2009, Ed. Bahaeddine editions.

[17] Polyphenols and Antioxidant Activity of Calafate (Berberis microphylla) Fruits and Other Native Berries from Southern ChileJournal of Agricultural and Food Chemistry (Impact Factor: 2.91). 05/2010; 58(10):6081-9.

[18] Z.Kaabouche, Cours et exercices de chromatographie. Ed Dar el fadjr. 2007, p109-189

[19] J. Parekh et Chanda S. V. In vitro antimicrobial activity and phytochemical analysis of some Indian medicinal plant. Turkish journal of biology., 2007,31 : 53-58.

[20] M. C.Rota, A.Herrera, R. M.Martinez, J. A. Sotomayor et M. J. Jordán , Antimicrobial activity and chemical composition of Thymus vulgaris, Thymus zygis and Thymus hyemalis essential oils. Foo d control., 2008 ; $19: 681-687$

[21] D. Lesueur, P. Pypers, Occurrence and genetic diversity of phosphate-solubilizing bacteria in soils of differing chemical characteristics in Kenya Ann Microbiol 2012 Vol 62 (897-904)

[22] H. Wagner, S.Bladt, Plants drug analysis: A thin layer chromatography Atlas. 2eEd. Springer, Berlin, New York., 1996., P: 77-96. http://dx.doi.org/10.1007/978-3-642-00574-9

[23] G.Chaib, S.Siah, A.Benabdelkadder, N.Bouchibi Baaziz and M.Benlaribi, Quantitative and qualitative study of phenolic compounds in three varieties of durum wheat (Triticum durum. Desf) and their activities antimicrobial. International Journal of Researchin Chemical, Metallurgical and Civil Engineering ( IJRCMCE) vol.2, Issue 1(2015) p:55-62. ISSN 2349 -1442 ESSN:2349-1450http://dx.doi.org/10.15242/

[24] A. Yaou A, Contribution à l'étude des composés flavinique d'une labiée ; Teucrium pollium. Thèse de magistère. 2001; $\mathrm{P} 102$.
[25] V.Bandyukova ., O. Shinkareako.,. The thin layer chromatography of Flavonoids,Chemistry of natural compounds ,1973;p:1-17-21.

[26] M. Lahouel, Interaction flavonoïdes mitochondrie et rôle de la propolis dans la prévention de l'apoptose induite par certains medicaments anticancéreux. Thèse de doctorat de l'université Mentouri de Constantine. 2005.

[27] U.Katarzyna, M.Anna, M.Marta, J .B Joanna., W. Grzegorz,.Assessment of antibacterial effects of flavonoids by estimation of generation ties in liquid bacterial cultures biologia; 2007;62(2) p: 135- 135.

[28] D.Harikrishna, A.V.N.Appa Rao, M .C Prabhakar., Pharmacological investigation of -6' O-p- coumarate: A flavnoid glycoside, Indian J pharmacol. 2004;36(4), p: 244-250

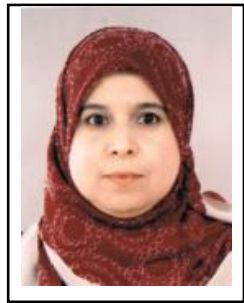

.CHAIB Ghania assistant Professor Laboratory of Development and Valorization of Resources Phytogenetics, Department of Biology and Ecology, Faculty of live Sciences and Nature University of Constantine Mentouri, Algeria. Birth 09/05/1968 Constantine. Algeria. Scientific Baccalaureates. 1987 Biochemistry DES : 1991Magister: Genetics and plant breeding..1998 PhD: Genetics and plant breeding. 2012

\section{On interest areas:}

Molecular biology, plant biotechnology, genetic engineering, biology and plant physiology, Secondary metabolism, water stress, cereals (Triticum and Hordeum) .Biodiversity.

Publications :

- Chaib G., et BenlaribiM.(2006).Proline accumulation in durum wheat (Triticum durumDesf.).under water deficit .Arab Univ J.Agric.Sci., Ain Shams Univ., Cairo,14(1),235-247.

- Chaib G., Hazmoune T. et Benlaribi M. (2008).Impact de stress hydrique s ique sur le test proline autant qu'indicateur à la biodiversité de blé dur .Annales de l'INRGREF, Actes des Journées Scientifiques de l'INRGREF, «La biodiversité dans les aires Protégées » Hammamet, Tunisie, 11-13 Novembre 2008.Numéro Spécial (12),2008.

- Chaib G., Bouchibi -Baaziz N., Hazmoune T et Benlaribi M. (2010).Indicateurs de tolérante au stress hydrique chez le blé dur ( Tritium durum Desf.).Le troisiéme Meetig International sur l'Aridoulture et les Cultures Oasiennes :Gestion et Valorisation des Ressources et Applications Biotechnologiques dans les agrosystemes Arides et Sahariens. Djerba,15-17 Décembre 2009.Tunisie. Revue des Régions arides. Numéro spécial 24(2/2010);634-638.

- Baaziz N., Chaib G. et Benlaribi M. (2010). Etude de quelques altérations physiologiques et biochimiques causées par la Septoriose (Septoria tritici Rob. Ex Desm ) chez le Blé dur ( Tritium durum Desf.).Le troisiéme Meetig International sur l'Aridoulture et les Cultures Oasiennes :Gestion et Valorisation des Ressources et Applications Biotechnologiques dans les agrosystemes Arides et Sahariens. Djerba, 15-17 Décembre 2009.Tunisie. Revue des Régions arides. Numéro spécial 24(2/2010) ;1280-1284.

- Ghania Chaib, Rachid Chaib et Ion Verzea(2009). From the risks evaluation to the health and safety preservation at work, Environment Engineering and Management Journal, Vo 18, N`3, Pp483-486, May/June 2009 ISSN : 1582-9596. Impact Facteur: 1.435 http://omicron.ch.tuiasi.ro/EEMJ/pdfs/vol8/no3/22_Verzea.pdf Chaib G., - Benlaribi M., et Hazmoune T. (2015) .Accumulation d'osmoticums chez le blé dur ( Triticum durum desf.) sous stress hydrique. Vol $11 \mathrm{~N}^{\circ} 24$ Août 2015 p : 378- 39. European Scientific Journal August 2015 edition ISSN: 1857 - 7881(Print) e - ISSN 1857- 7431.

- Chaib G., Siah S., Benabdelkadder A., Bouchibi Baaziz N. and Benlaribi M., (2015). Quantitative and qualitative study of phenolic compounds in three varieties of durum wheat (Triticum durum. Desf) and their activities antimicrobial. International Journal of Researchin Chemical, Metallurgical and Civil Engineering ( IJRCMCE) vol.2, Issue 1(2015) p:55-62. ISSN 2349 -1442 ESSN :2349-1450 .

http://dx.doi.org/10.15242/ IJRCMCE.E0915022. 